\title{
Can Willingness and Hands-on Work Together? Teaching Biological Evolution and Dealing with Barriers
}

\author{
Ozgur Taskin
}

Published online: 23 June 2011

(C) Springer Science+Business Media, LLC 2011

\begin{abstract}
This qualitative research aims at first defining how pre-service science teachers think regarding the theory of evolution (TOE) with a particular hands-on and minds-on activity (The article by O'Brien (Am Biol Teach 62(8):578-582, 2000) entitled A toilet paper timeline of evolution: $5 \mathrm{E}$ cycle on the concept of scale is modified and applied in the present research as an intervention process.) Finally, specific suggestions in instructional techniques are offered based on a geological time scale. At the end of intervention, the research follows how participants respond to what they found out or came across. If participants had common misconceptions regarding the TOE, these are revealed. The present research was conducted in two spring semesters of 2009 and 2010 in a geology course. The participant number of the study was 129. The research lasted three weeks. Research results showed that participants were generally misinformed regarding conceptual knowledge of the TOE. Approximately half of the participants did not believe (the term believing in or acceptance of the TOE does not affect research findings) in the TOE. Mostly, they thought that there is no place for human evolution in Islam. Few of them could reconcile scientific information with their own Islamic point of view. Even though they did not believe in the TOE, most of them accepted that they did not have adequate knowledge regarding the TOE. They mostly said they were shocked about the first appearance of human beings in the geological time scale, which is the main issue in the present research. After intervention, conceptual
\end{abstract}

O. Taskin $(\bowtie)$

Biology Education Department, School of Education,

Ondokuz Mayis University,

Samsun, Turkey

e-mail: omuozgurtaskin@gmail.com

e-mail: otaskin@omu.edu.tr change was considerable, though this is a secondary concern. The results also show that even though students were quite prejudiced regarding the TOE, they were ready to explore it deeply. Such concrete activities might be helpful to push students to think over the TOE. However, there are numerous barriers such as ill-prepared science textbooks and websites, unwillingness of instructors, and official policy of the Ministry of National Education.

Keywords Teaching evolution · Misconception · Geological time scale $\cdot$ Fossil record $\cdot$ Conceptual change

\section{Introduction}

Teaching the theory of evolution (TOE) is one the most challenging issues in the area of science education (National Research Council 1998). Needless to say, there are numerous barriers for both teaching and learning the TOE. Individuals might have strong presumptions because of their own life experiences. Personal religious affiliation might have an influence on acceptance of the TOE. Even these affiliations might create conflicts in one's scientific thinking skills. Epistemological problems such as misuse of the term theory (National Research Council 1996) and the nature of science (NOS) might also create a problem. This misuse also might be intentional in the frame of political willingness. Meanwhile, teaching materials including official textbooks, internet websites, and such materials, might not be prepared scientifically. Sometimes, science teachers might not be willing to teach the TOE (Griffith and Brem 2004). Learners might also not have scientific orientation and might have misconceptions regarding the TOE. Last but not least, individuals have quite low understanding regarding the NOS (Demastes et al. 1995). The aforemen- 
tioned reasons are just some of the problematic issues both for teaching and learning the TOE.

In addition to the above problems, specific attacks against to the TOE should be promptly taken into account whether these attacks are intentional or not. For instance, most of the time, the TOE has been presented as an ideology and given a name, so-called Darwinism. The TOE can even be linked with pornography (Overman's work, cited in Gibson 2004) and racism in Western societies in some activist circles-particularly in the United States. Not surprisingly, in some Muslim countries, the TOE may have been presented as a product of Masonic baloney or Communism.

The first aim of the present research is to find out how pre-service science teachers think and respond regarding the TOE with a specific hands-on and minds-on activity based on the geological time scale, then what kind of misconceptions they hold, and potential reasons if they do. Meanwhile, whether participants can comprehend the TOE and change their previous thoughts regarding the TOE is also discussed in the context of their written reactions.

\section{Literature Review}

One recently published article shows that Turkish people stand against the TOE (Miller et al. 2006). There are few studies revealing the exciting situation in terms of the TOE in Turkey, though, unfortunately, conducted research has not been based on intervention. Ironically, suggestions are mostly based on a constructivist approach. Basically, researchers have taken for granted that the TOE has been taught in Turkey, although students have not learned for various reasons such as mechanistic teaching at the college level as claimed by Deniz et al. (2008). Unfortunately, the research results of Apaydın and Sürmeli (2009) and Peker et al. (2010) show that Turkish undergraduates who major in science education and biology have quite a low acceptance rate for the TOE. According to the study by Peker et al, most of the biology courses in Turkey at the undergraduate level have not been given scientifically. Again, the same study shows that overall acceptance rate of the TOE is around $28 \%$. Guessum's findings reveal a more pessimistic result than the findings by Peker et al. The results show that in Muslim/Arab countries including Turkey, acceptance of the TOE is around $15 \%$. Guessum also points out that TIMMS results are also quite an indicator of failure of Muslim students between the fourth and eighth grades (Darwin Anniversary Symposium 2009).

In spite of little research in Muslim countries, there are numerous studies regarding critical facets of the TOE in Western countries at all levels. On one hand, constructivism has been supported in the context of U.S. national science education standards (National Research Council 1996); however Terry (2004), which alerts readers regarding the new definition of science and discusses some institutions' attempts to place Intelligent Design (ID) instead of the TOE in science curricula. Leonard (2004) underlines another critical issue, which is ill-prepared biology textbooks. It should be noted that the U.S. national science educaion standards depend on the spirit of the NOS. In short, science education standards, constructivism, and the NOS have been melted in the same pot. However, the instructive process may change from country to country.

For instance, in France, the TOE has been taught at the primary education level, and the results released in qualitative version are remarkably successful. According to Chanet and Lusignan (2009), as long as the TOE has been taught systematically, willingly, and at the proper age, the age of the learner might not be a problematic issue. A similar research result shows that there is strong positive correlation between practical applications (handson activities, etc.) and higher-level thinking processes of students. Thus, the terms regarding evolution and its mechanism make more sense for seventh grade students (Anderson et al. 2001).

Other conducted studies at the undergraduate level generally suggest social negotiation between students and teachers and alternative instructional techniques (Ingram and Nelsons 2005; Hermann 2008; Brem et al. 2003).

However, some counter arguments also can be found in research findings. Sinatra et al. (2003) emphasize conceptual change. They claim that it can be a naive thought that students will be able to grasp the theoretical background of the TOE as long as an appropriate pedagogical technique is applied. Not surprisingly, even medical school students in Scotland have similar tendencies (Downie and Barron 2000). Reluctance of a student or teacher, an unequipped instructor, and teaching materials regarding the subject matter will most likely affect both the teaching process of the TOE and its mastery. The findings of Buehl and Alexander (2001) and Hofer (2000) also reveal similar results.

Obviously, there are numerous suggestions regarding dealing with teaching the TOE. Now, the question is what has gone wrong? Scharmann (1993) points out that biology and science teachers should be equipped both instructionally and in subject matter level properly; otherwise, the expected outcome for teaching of the TOE might not be achieved. However, Moore's research shows that even though teachers believe that they really teach the TOE, students do not share same feelings (Moore 2007). Interestingly, the aforementioned study was conducted in Minnesota where the standards of science education are far above the national level. On this point, the question by Jenkins (2001) makes perfect sense: "Is this [constructivist 
perception of science education] a dangerous intellectual tendency or not?" However, Hokayem and BouJaoude (2008) suggest that religious beliefs should not be viewed as a misconception, rather an "individual's cultural milieu" which should be analyzed correctly. Lombrozo et al. (2006) discuss moral issues in the frame of misconception.

Good (2003) specifically mentions political pressures over academics and points out that even though teaching biological evolution is perhaps not politically correct, it is scientifically correct. For instance, in some circles, ID has been presented as a scientific truth for the last two decades on behalf of constructivism and postmodern science education. Hallgrimsson (2008) specifically stresses that ID is a reaction against modern science in the U.S. It is well known that these attacks against modern science have been the subject matter of court cases in the U.S. since 1925 (Moore 2000). Similarly, specific attacks in the Turkish educational system in the last 30 years have been disseminated (Sayın and Kence 1999; Peker et al. 2010) however; the Turkish scientific community is commonly silent regarding these attacks. It is almost impossible to find such a court case or defensive arguments against science curriculum in Muslim countries-with some exceptions in Turkey (UKD v MNE 2006). Incidentally, it should be noted that Turkey is an official candidate for the European Union (EU). Ironically, the Turkish education system has not been criticized even once by EU Members in this period.

The present research is the first qualitative research that attempts to evaluate whether pre-service science teachers can grasp the TOE better with a simple combination of hands-on and minds-on activities in Turkey. Finally, the existing misconceptions of pre-service science teachers are revealed through participants' own statements. Existing conceptual changes, if they occur, are also revealed.

\section{Methodology}

The present research was conducted in one of the comprehensive universities in Turkey during the academic year of 2009 and 2010 in the course sessions called "FBA 308 Geology." The total number of students in the university is around 20,000. The number of students in the school of education is around 7,500. Approximately, 400 of them major in the department of science education. Some courses and hours participants took during the research process are as follows: biology, $(10 \mathrm{~h}$ including $2 \mathrm{~h}$ lab section), chemistry ( $20 \mathrm{~h}$ including $4 \mathrm{~h}$ lab section), and physics (14 $\mathrm{h}$ including $6 \mathrm{~h}$ lab section). Some of the codes of these courses are FBA (Science Education Area Courses) 101, 102, 103, 104,105, 106,107, 108 (first year); 201, 202, 203, 204, 205, 206, 207, 208, 209 (second year); 302,303 , and 305 (third year).
The participants were junior undergraduate students majoring in science education. At the beginning of the study, the total number of participants was 154 from six different classes. All participants joined in the present research voluntarily. However, 25 students who attended in the first week of research dropped the other sessions of research.

The data were collected as an essay document. The aforementioned technique is preferred rather than an interview one. There are two reasons as follows: first, since the topic is controversial, students might not define themselves openly in the face-to-face interview process. Second, since the participants are not identified on the questionnaire sheet, they write down their own opinion frankly, supporting trustworthiness of the data. For instance, participant [54] said "...the activity was joyful because we could say our thoughts freely. When we say against any idea of the TOE, we could be threatened by the other instructors which did not happen here in this course..." Similar quotes can be found in the essay documents. Thus, it should be noted that the researcher is strongly confident regarding the validity of findings.

The intervention was administered to all six classes in the same pedagogical format by the same researcher. As an instructional technique, the recommendations by Scharmann (2005) were strictly followed as asserted in the National Science Education Standards (National Research Council 1996). These standards call for student active participation with small working group, discussions with peers, and interpersonal relations with student and teacher.

The study included three stages. And each state lasted approximately two hours. These are as follows:

In the first week of research, the working groups were organized by students, depending on their own personal willingness with whom they would like to work. The number of group members varied between three and four. In the first week, three main questions were posed to students. Each group member worked together to write down their answers on the paper after a half-hour of brainstorming. The written documents were taken back by the researcher. The questionnaire can be found in the Appendix.

Due on the following week: Each working group was asked to come with the geological time scale, one roll of toilet paper, sticky labels, and calculators to the classroom in the following week.

In the second week, the application process was videotaped by a student. First, the students were asked to roll the toilet paper all the way down the hallway. Basically, the toilet paper (approximately $25 \mathrm{~m}$ ) represents the age of the Earth, which is $4.5 \times 10^{9}$ years. They were asked to guess when the first modern human being (Homo sapiens 
sapiens) fossil record had been found and mark it on the toilet paper (Prediction). Then, students were asked to mark some other fossil records in order: first one-cell microorganism, first terrestrial plant, the appearance of dinosaurs, first phanerogam-cryptogam, extinction of the dinosaurs, the first mammal, and finally, modern human beings. The participants used their calculators and marked all fossil records according to the geological time scale.

In the third week of research, students was asked five questions and wrote down their own opinions. The questionnaire can be found in the Appendix.

All written documents were analyzed in the frame of typological analysis according to Hatch (2002, pp 152161). To do that, open coding was used (Strauss and Corbin 1998, pp. 101-142). The participants' written documents were categorized as informed pro-evolutionist, uniformed pro-evolutionist, skeptic, neutral, and uninformed antievolutionist. First, the researcher analyzed the data. Then, data were analyzed by another area expert in science education. After getting consensus regarding data analysis process, the researcher picked the most representative participants and their own quotes.

\section{Findings}

First Week Application

According to the working groups' answers, mainly geologists and archeologists are known to estimate the age of the Earth. The other science branches were named in order as mineralogy, geochemistry, and petrology. All participants agreed that the age of the Earth is around $4.5 \times$ $10^{9}$ years. However, there are different opinions regarding how the age of the Earth is determined. These are as follows:

1. The theory of continental drift

2. Basically, it could be based on the first fossil records

3. Carbon dating

4. Radioactive half-life

It is not surprising that most of the participants' thoughts regarding estimates of the age of the Earth are based on non-demonstrative applications such as continental drift, and radioactive half-life. However, the group participants could hardly compare a million years with something that they know. Since almost none of the participants knew when the most popular prehistoric organisms such as the dinosaurs first appeared and went extinct on the Earth, most of the participants thought that prehistoric humans and dinosaurs lived in the same historical period. In short, one million years resembled nothing to the participants, and their knowledge of the fossil record was quite low; they knew almost nothing about the fossil record.

\section{Second Week Application}

Each group came with their equipment to the classroom. They rolled down a roll of toilet paper and measured it. To do that they just measured a single of sheet and counted them all. Length varied between 20 and 25 meters. First, the predictions were gathered regarding modern human being fossil records and dinosaurs. The students mostly marked between 5 and 15 meters and thought that modern human beings and dinosaurs lived in the same period. Second, they were asked to begin to mark on the toilet paper the most popular living organisms according the fossil record with their own geological time scale. These were: first one-cell microorganism $\left(3.8 \times 10^{9}\right)$, first terrestrial plants $\left(450 \times 10^{6}\right)$, first appearance of dinosaurs $\left(250 \times 10^{6}\right)$, first phanerogamcryptogam $\left(145 \times 10^{6}\right)$, disappearance of dinosaurs $\left(65 \times 10^{6}\right)$, first mammal $\left(24 \times 10^{6}\right)$, and modern human beings $(0.2 \times$ $10^{6}$ ) years. They marked these fossil records and then discussed what they found. The researcher did not get involved in this process but let the group members discuss because this approach is more appropriate to the format of constructivism. The discussion process takes approximately half an hour.

\section{Third Week Application}

Finally, in the last week of research, a questionnaire sheet with five questions was given to each participant (in the Appendix). After the participants wrote down their thoughts regarding questions, each questionnaire paper was given a number such as [1], [2].

The most well-informed participant (participant [7]) regarding the TOE said:

This is a process that shows all organisms have come through a common ancestor...The mechanism of evolution is so complex. To comprehend it, one should have adequate knowledge...Since evolution has come over the billions of years; one cannot see a concrete form of evolution [Macro evolution]. However one can estimate the process of evolution with fossil records. That is why I believe in evolution...After this application, nothing changed for me. The presence of different organisms since the Earth existed is a concrete proof for evolution. The organisms which cannot adapt to the environment could not survive-that is explained by natural selection... according to me, this activity should be applied to the people who are scientifically literate. Otherwise, a person who does not know anything about biology cannot be different from a lay person. 
Even though participant [7] was the most wellinformed about the TOE, s/he couldn't say anything about population genetics. According to the participant, adaptation is the result of environmental conditions and evolution is a complex process. The second important issue is $\mathrm{s} / \mathrm{he}$ was the only participant who underlined the importance of scientific literacy. Lastly, the participant pointed out that people are quite illiterate regarding biological concepts. It should be noted here that the participants were pre-service science teachers.

Participant [14] declared her/his opinions as follows:

The evolution process explains the change from the first step of existence of microorganism to the human being [Macro evolution and progressivism]. These developments reveal the changes from archaic microorganism to the most complex one...Speaking of the mechanism of evolution, generally the evolution process brings to my mind a process which is coming from monkey to human being...There are things that I believe in evolution as much as I do not. Why do not I believe? According to this thought [evolution], the roots of human being come from the monkey. If this is true, then it is supposed to be that all monkeys should turn into human beings. If evolution means changing, this should have been like what I said. But this does not happen...When I applied this hands-on activity, I comprehended that we did not know anything about evolution. We just know what we have heard. With this activity, the existence of human generation is hardly noticeable compared to the age of the Earth.

Even though participant [14] accepts that s/he lacks adequate knowledge regarding biological evolution, s/he does not believe in the TOE. However, the participant cannot tell what $\mathrm{s}$ /he does not know about the TOE. Common misconceptions are still based on coming from the monkeys and evolution is a progressive process. The participant can be categorized between skeptic and uninformed anti-evolutionist. Upcoming participants' utterances reveal why students have this particular misconception.

Participant [20] only answers one question and follows up saying:

"I do not believe in the TOE because I merely believe that Allahu Ta'ala (the God) created human being [based on Qu'ran doctrine-uninformed antievolutionist]."

As a pre-service science teacher, s/he categorizes the living organism and human being differently. This misinformation can be found in most biology textbooks in Turkey.
Participant [21] says "...But there are many misconceptions such as Darwin claims that human beings came through the monkeys" and follows up "...we cannot say that religion (Islam) does not reject the TOE. As a result Qu'ran says that we (human beings) all were made of water and soil." Similar thoughts can be found in other research (Dagher and BouJaoude 1997). However, integration of science and religion or basically reading the scripture in a scientific way is quite rare for the Islamic point of view [Integration science and religion-Neutral] and it should not be considered in the frame of scientific explanation.

Participant [22] says "I do not believe in TOE. The human being was made of water and soil. The ancestor of human beings is known. We [human beings] did not change. People say we evolved from monkeys. I do not agree with this idea." [based on Qu'ran doctrine-conflict between science and religion-uninformed antievolutionist].

Even though participants [21] and [22] use the same rhetoric, the former participant shows the idea of integration, the succeeding one grasps conflict between religion and the TOE. Participant [22] follows up saying:

They [my thoughts] did not change because it is almost impossible to convert a person's thought at a particular age. I do not believe that my thoughts will change...The activity was interesting. If this activity is applied for youngsters with certain explanation, it is possible to shape their minds. However our thoughts [her/his peers] are rigid." This finding can also be supported by Sinatra and coworkers' (2003) research. Participant [25] says:

As a matter of fact, before this hands-on activity, evolution has brought to my mind that human beings have come through monkeys. The textbooks [Ministry of National Education's official publications] enclose this kind of photos...Till this year, I have never believed in the TOE. When I have read some books, I always find some logical and illogical things; however, many things actually make sense now...I read a book. This book never implies human beings come through monkey...It is more like our ancestors looked like monkeys. It is not the same...With this activity, I really saw the difference between the age of the Earth and existence of human beings.

According to participant [25], books are quite important that give a shape to one's mind; however, even official books are not written scientifically. If one reads proper scientific sources, it is possible to change one's mind. The participant can be categorized as skeptic or uninformed pro-evolutionist.

Participant [27] says "At the beginning, I thought that the TOE is a theory that supports human beings come 
through monkeys; that is why I could not believe in. After getting more information regarding it [TOE], now it makes sense...I began to see the world with the eyes of different organisms. The world does not belong to us..." [Damage of anthropocentric thought]

Participant [28] highlights that $\mathrm{s} /$ he does not believe in the TOE and says "Because there is no exact definition [regarding the TOE]; its definition depends on which book you read...While speaking of the TOE, textbooks mostly include photos picturing turning from monkey to the human being. However, the TOE does not have this argument. It is too wrong to use this kind of photos." [Even though the participant knows aforementioned drawback for textbooks, $\mathrm{s} /$ he does not believe in the TOE]. Participant [39] points out the same problem. "Books are the most important negative effect on us." Clearly, it might be said that the textbooks are ill prepared. These textbooks contain specific misinformation in Turkey (Peker et al. 2010). Rees (2007) in England and McCarthy and Sanders (2007) in South Africa similarly point out how science textbooks are not adequate and include ill definitions regarding the TOE.

Participant [30] reveals another internalized misconception. "[the TOE] it is not valid anymore...Look at the websites...because none of the complex organisms can result from a prokaryotic cell. There is no useful mutation model, but the TOE is built up on useful effects of mutations." The participant believes that mutations cannot be constructive (useful). This is the first misconception. The second is that the TOE merely depends on mutations. ${ }^{1}$ The participant discusses the validity of the TOE according to what $\mathrm{s} / \mathrm{he}$ has learned from some Internet websites. The participant can be categorized under an uninformed antievolutionist. Participant [33] says:

I think it [the TOE] is baloney. This is totally fabricated by the science community to wipe out religion...I do not know anything about the TOE...It is all about atheism. Who cares what you [the instructor] say...Maybe you made people confused with this hands-on activity though you cannot deceive me. Whatever you do, the Earth, human beings, and all creatures were created by Allah. You cannot disprove it...Good trick, good job.

Even though the utterances by participant [33] show that $\mathrm{s} /$ he is strongly opposed to the TOE as an uninformed antievolutionist, this application creates an inquiry and cognitive interrogation process for the individual. $\mathrm{S} / \mathrm{he}$ reveals her/his indisposition towards the TOE strongly-even sometimes offensively.

\footnotetext{
${ }^{1}$ Inversion in living organisms, sexual reproduction etc. are some of the examples for the term mutation.
}

Participant [52] similarly declares her/his rejection of the idea of biological evolution and follows up, saying "...I realized that some pieces of the puzzle [the TOE] lack. These problems regarding the TOE make me not to believe in it. Thus, I am supposed to read more resources...The huge time gap difference between the age of the Earth and fossil records of human beings made me surprised though nothing changed regarding the TOE in my mind. It was quite an effective activity."

Participant [54] says: "I do not believe in the TOE because if everything has evolved then how and from which organism human being has been evolved. I am wondering this answer. The creator, Allah, says in Holy Qu'ran in some verses such as in Ikra and Yasin, we [human beings] were created from nothing. We were not evolved from another organism. These ideas [the TOE] are sick and help atheist people cheer up themselves...The activity was joyful because we could say our thoughts freely. When we say against any idea of the TOE, we could be threatened by the other instructors"

Participant [70] says: "I do not know anything [regarding the mechanism of biological evolution]. I do not believe in the TOE because it does not look logical turning one creature to another one. For instance, some people say human being is the descendant of monkey. These people are supporters of the TOE. Many experiments prove that this is not possible. Still I do not believe in the TOE [after activity]. I do not think that 200,000 years of first appearance of first human being proves anything to me regarding the TOE."

Participant [102] declares: I do not know anything about the TOE. I do not believe in it because it is impossible for an organism to change too much to adapt itself. I think an organism still keeps the same form how it was created. Participants [70], [93], [102], [105], and [106] are just five of the uninformed anti-evolutionist who do not know anything about the TOE and do not believe in it either.

Meanwhile 25 participants declared that their thoughts regarding the TOE changed positively. Mostly, they pointed out the first appearance of the human being on the geological time scale. For instance, participant [81] says "...Yes my opinion has changed [regarding the TOE]. The huge difference between the age of modern human being and the earth is too much..." Participant [129] says, "I really do not know anything about the TOE...However, I have never thought that the first appearance of human being and the age of Earth could be like this. I had had no idea of this much time gap. I applied the activity but still I cannot visualize it. I am shocked." Similarly, Participants [99] and [103] declared that their thoughts had changed. This conceptual change is mostly based on the huge time gap 
between the first appearance and the age of the earth. It also shows that even though participants are not well informed regarding the TOE, participants might tend to accept the TOE.

Participant [55] associated the TOE with Marxism and Leninism-even with socialism. The same participant also supports the censorship regarding Darwin's article in popular science magazine Science and Technology which is funded by an official government science academy (Abott 2009). The participant follows up saying "Darwinism is a perverted idea which has been supported by the atheists that is why I do not believe in the TOE... I am really confused...Hope, I do more search [to learn regarding the TOE]. But where are the transition forms? After 150 years, why is the TOE still theory not a law? Still I am not satisfied. Still, I should ask many questions... I liked the activity. It is everlasting activity (easily-remembered). I would like to use this activity in my class."

Participant [55] is neither politically nor scientifically correct and reveals common misconceptions and epistemological problems. Meanwhile, it appears that the participant is strongly religiously opinioned. According to the participant, a particular circle of members (pro-evolutionists) have imposed the ideas of Darwin on society. A common epistemological problem regarding the definition of theory is also another finding which can be supported by previously conducted studies in Turkey (Taskin and et al. 2008). The participant also looks for transitional forms for the proof of the TOE; however these transitional forms are defined as freaks, such as fish with wings, an organism with an elephant trunk. Participant [56] similarly says that "I would like to believe in the TOE however I cannot see it." It is not surprising to find these examples because readers mostly use misinformed internet websites such as Harun Yahya's.

After accepting that participant [29] does not know anything about the TOE, s/he continues "It is impossible to say whether I believe in or not the TOE. However, so far I have not believed in the TOE...I know that there is change...But I really wonder, does evolution say that human beings have come through monkeys? Could you tell us this in the course?...Only this activity did not change my thoughts; however I perceived that I never questioned many issues before this hands-on activity. I am quite surprised to see that we [human beings] have a short history on the Earth. Now more than believing or not the TOE, I am really confused." As mentioned before, the instructor neither gets involved in the active discussion process nor gives a lecture regarding conceptual knowledge of the TOE. However, the utterances clearly reveal that the pre-service science teachers desperately look for a valid informant.
Even though some participants are quite antievolutionist, utterances also show that they feel quite comfortable during the application of activity. The research results of Haidar (1999) also support and, most importantly, challenge us with critical questions. According to Haidar's finding, "Constructivist views can be attributed to religious beliefs. Students' views that scientists cannot see the real thing is consistent with the Islamic understanding that only God (the Great Knower) knows the real truth.” Thus, the existing inclination of most of the participants is quite understandable.

\section{Implications and Conclusions}

The findings are important for several reasons, as follow: first, the present research has been designed within the framework of constructivist pedagogical approach, though findings have been analyzed in a critical perspective. Second, even though results are quite promising for this specific research, contrary to these findings, general opinion regarding teaching biological evolution in Turkey (which is the most Westernized Muslim country) is quite pessimistic. In light of these findings, common misconceptions, ill-used terminology, and conceptual change issues are pointed out in this section. Depending on participants' own declaration, how they have thought regarding the present activity and why they are opposed to the TOE are also revealed.

\section{Misconceptions and Conceptual Change}

Participants both who have accepted and not accepted the TOE speak out frankly and declare that they have almost no conceptual knowledge regarding biological evolution in the present study. Adaptation, population, speciation, mutation, common ancestor, transition form, and variation are mostly ill-used terms (Table 1). For instance, the individual is considered a key component, rather than population, in the context of evolution. Adaptation is deemed a consequence of environmental effects; however, population genetics (gene pool) is not mentioned by the participants. Participants disregard the TOE because biological evolution imposes on them the monkey as a common ancestor. According to the participants who do not accept the TOE, transitional form represents a freak organism. Aforementioned misconceptions are quite common for the participants, almost for everyone. Interestingly, the participants' most important misconception is regarding the geological time scale. They know almost nothing about the first appearance and disappearance of any organism. Fifty-eight participants declare their misconception regarding the geological time scale. Twenty-three participants point out that the activity is concrete and eleven of them find the activity entertaining. 
Table 1 Key words which participants used in the essay documents

What do you think regarding the evolution of living organisms?

\begin{tabular}{lllll}
\hline Change (31) & Mutation(8) & Variation (2) & One ancestor & Time (2) \\
Environment (3) & Natural selection (6) & Weak character & Changing species & Common ancestor (12) \\
Process (15) & Fossil & Monkey (2) & Environmental Conditions (4) & Adaptation (11) \\
Changing to another species & Speciation (7) & Permanent & Development (7) & Structural change \\
Different species (2) & Coming from one cell (3) & Environment & Differentiation (2) & Extinction (2) \\
Progress (13) & Diversity (3) & Transitional form & Baloney & Pictures like monkey \\
Logical (2) & Climate & Geography & Metamorphosis (2) & Formation(4) \\
\hline
\end{tabular}

Regarding effectiveness of the activity for accepting the TOE, 25 participants declare that their previous opinion changed positively toward accepting the TOE. Most of them, even the participants who do not accept the TOE, are stunned by the first appearance of human beings on the toilet paper. The most amazing outcome of the study is that students have begun to hold confused and suspicious thoughts regarding the TOE (Table 2). Participants' reactions and thoughts are quite important. Even though participants might not be interested to learn the TOE, these confusions regarding the geological time scale might incline them to think about the TOE. However, except for some metropolitan universities, either biology courses have not been given properly or there is no course regarding biological evolution in Turkey (Peker et al. 2010). Meanwhile, Moore et al. (2002) strongly points out that languages of evolutionary theory should be an integral part of the evolution curriculum. Unfortunately, in Turkey, we do not have science education, namely a biology education curriculum, based on evolution.

I humbly can say that even after six hours of application, which is relatively short, improvements in the cognitive level of participants are quite amazing in the present research. However, unfortunately, the Ministry of National Education (MNE) has not intended to teach the TOE for the last 30 years (Peker et al. 2010). There is no scientifically and officially prepared software, textbook, or even a chapter in a textbook regarding the TOE. The TOE has been presented as a hunch and granted not more than two unclearly written paragraphs in science textbooks. It should be also noted that there are numerous mistakes in officially prepared textbooks regarding the TOE (Peker et al. 2010).

Table 2 Classification of participant numbers according their answers whether they believe in the TOE after intervention

If your thoughts changed after this hands-on activity, in what way did it change? Categories

\begin{tabular}{lllll}
\hline Believe in & Not believe in & Suspicious & Neutral & Change \\
56 & 37 & 10 & 26 & 25 \\
\hline
\end{tabular}

Interestingly, MNE still defended scientific aspects of these science textbooks in a court case. Some of the arguments of MNE to support the defense are as follows:

(a) Discovery Institute, in the United States, held a meeting with hundreds of scientists who a scientific opposition against Darwinism

(b) States develop the curriculum according to their citizens' culture and life style in light of scientific pathway...After teaching merely the TOE in the courses, developed countries now also began to teach Creationism

(c) The TOE is [just] a theory (UKD v MNE 2006)

This defense of the MNE goes against the spirit of both constructivism and the NOS. It is also clear that the present defense does not support inquiry-based science education curriculum in Turkey, which is based on the National Science Education Standards (National Research Council 1996). However, MNE claims that science education curriculum in Turkey is based on National Research Council guidelines. At this point, the warnings of Lombrozo et al. (2008) are quite important. The scientific and colloquial uses of theory differ; however, the MNE still prefers the colloquial one.

\section{Why Are Students Opposed to the TOE?}

Most of the participants who do not accept the TOE refer to their own Islamic points of view. However, as mentioned earlier, they do not give any scientific explanation or reason to sustain their thoughts. Mostly, they refer to God as a creator. There is no sign that shows participants are aware of the term Intelligent Design, though Matthews (1998) critically warns the scientific community to distinguish what the NOS really means. It should be noted that teaching evolution and the NOS have a strong association. However, some of the participants directly link the TOE with political affiliation, particularly with socialism. Most of the participants have either strong religious affiliation or/ and conservative unscientific explanations. Some of the participants show quite strong reactions against liberal and 
left-inclined values and might easily be politically incorrect. Even though this finding may not seem compelling, this is the general public's understanding regarding the TOE, including some academic circles in Turkey. To teach the TOE, suggestions are mostly based on constructivist aspects such as the research by Deniz et al. (2008). These authors claim that the TOE has been taught by a mechanistic teaching style in Turkey; thus, students cannot comprehend the TOE. However, one of the authors of this article releases his own sincere opinion about censorship in a Darwin article issued by the Nature (Abott 2009) and says: "But there are some comments on science where the ideological aspect begins here at this point. All comments between the lines in many articles are appropriate to the atheist and evolutionist perspective... In general the theory of evolution or Darwinism (for all versions) is still far beyond a scientific point of view and it is a whole pack of faith merely based on hypothesis... Mostly in the U.S. and, in many other countries there is a strong opposition against evolution...The curious could easily find many documents on the Internet against evolution...the Discovery Institute, the Institute for Creatiion Research, and the John Templeton are some foundations that publish these kind of books." (Zaman Newspaper 2009). Even though similar comments can be perceived as freedom of speech in society, they might create ambiguity and bias effects regarding both suggestions and the application process of scientific research conducted in Muslim countries.

\section{Proper Pedagogical Formats with Reliable Instructors Based on Seeking Inquiry}

Finally, 56 participants clearly declared that they believed in the TOE and 37 of them defined themselves as unbelievers of the TOE. Twenty-six participants remained neutral. Ten of the participants were skeptical rather than being a believer or not. As Sinatra et al. (2003) said, even though an instructor applies the most appropriate pedagogical techniques in the classroom, outcomes of the course might not be satisfactory. Clearly, unless a learner is willing to make an inquiry, results cannot match acceptable outcomes. As mentioned earlier, the participants were quite conservative students who had not taken any courses regarding the TOE or biological evolution. They had mostly read unscientific, untrustworthy websites and textbooks. Even after all the drawbacks the researcher faced throughout the study, participants' key comnents show that there are two crucial points which should be underlined for the present study. First, the researcher should be reliable and confident. Second, the researcher should make a learner face her/his own lack of conceptual knowledge, misconceptions, and epistemological problems. The responsibility regarding whether or not to learn belongs to a learner. In this present study, I am optimistic regarding the outcomes. For instance, 25 participants out of 129 responded positively to question III.4 (Appendix). Even non-believer participants presented their feelings with strong exclamations such as "good trick... good job," "I am confused," "It was a good trick," "I have never learned this much till this year," and similar quotes. They also do not feel their religious faiths are hurt-which is crucially important.

Making a Decision: Solipsism or Inquiry-Based Science Education

It should be noted that the curricula in Turkey are prepared and administered by a centralized authority, the MNE, which depends on government intention. If the science curriculum is really based on constructivism and inquiry-based science education, first of all, international bibliographies should be used properly, such as the National Science Education Standards (National Research Council 1996), and Benchmarks for Science Literacy (American Association for the Advancement of Science 1993). Second, science textbooks should be prepared carefully and should include an evolution section. Otherwise, all attempts unfortunately might not succeed. As a final statement, the governments' official education policy might be based on constructivism but also should stress the importance of scientific process skills and willingness to teach the TOE at all levels. If not, science education in Turkey might be grounded in solipsism on behalf of the misuse of constructivism.

\section{Appendix}

First Week Questions

I.1. How can scientists determine the age of the Earth? Which techniques do they use? According to the scientists, how old is the Earth? Do you agree with these findings?

I.2. Please try to imagine one million years. Could you compare this amount of time with something else? Could you give some examples?

I.3. How do scientists decide which and how long species have existed on Earth? Could you list the lifespans of some popular species on Earth?

Third Week Questions

III.1. What do you think regarding the evolution of living organisms? 
III.2. What do you know about the mechanism of biological evolution? Please discuss on paper.

III.3. What are the reasons why you do or do not accept the TOE?

III.4. If your thoughts changed after this hands-on activity, in what way did they change? Please list the reasons. For instance, what do you think about the relationship between the age of Earth and the first recorded hominid fossil?

III.5. Could you write down your own thoughts regarding this activity?

\section{References}

Abott A. Turkish scientists claim Darwin censorship. Retrieved May 9, 2009, from http://www.nature.com/news/2009/090310/full/ news.2009.150.html

American Association for the Advancement of Science. Benchmarks for science literacy. New York: Oxford University Press; 1993.

Anderson OR, Randle D, Covotsos T. The role of ideational networks in laboratory inquiry learning and knowledge of evolution among seventh grade students. Sci Educ. 2001;85(4):410-25.

Apaydın Z, Sürmeli H. Üniversite öğrencilerinin evrim teorisine yönelik tutumları [Undergraduate students' attitudes towards the Theory of Evolution]. İlköğretim Online. 2009;8(3):820-42.

Brem SK, Ranney M, Schindel J. Perceived consequences of evolution: college students perceive negative personal and social impact in evolutionary theory. Sci Educ. 2003;87:181-206.

Buehl MM, Alexander PA. Beliefs about academic knowledge. Educ Psychol Rev. 2001;13:385-418.

Chanet B, Lusignan F. Teaching evolution in primary schools: an example of French Classrooms. Education and Outreach. 2009;2 (1):136-40.

Dagher ZR, BouJaoude S. Scientific views and religious beliefs of college students: the case of biological evolution. J Res SciTeach. 1997;34(5):429-45.

Darwin Anniversary Symposium (2009). The challenges of science education today. Nidhal Guessuoum 'un sempozyum bildirisi. 2225 Nisan, Istanbul.

Demastes SS, Good RG, Peebles P. Students' conceptual ecologies and the process of conceptual change in evolution. Sci Educ. 1995;79(6):637-66.

Deniz H, Donnelly LA, Yilmaz I. Exploring the factors related to acceptance of evolutionary theory among Turkish preservice biology teachers: toward a more informative conceptual ecology for biological evolution. J Res SciTeach. 2008;45(4):420-43.

Downie J, Barron N. Evolution and religion. Attitudes of Scottish first year biology and medical students to the teaching of evolutionary biology. J Biol Educ. 2000;34:139-46.

Gibson MT. Culture wars in State education policy: a look at the relative treatment of evolutionary theory in State science standards. Soc Sci Q. 2004;85:1129-49.

Good R. Evolution and creationism: one long argument. Am Biotechnol Lab. 2003;65(7):512-6.

Griffith JA, Brem SK. Teaching evolutionary biology: pressures, stress, and coping. J Res Sci Teach. 2004;41(8):791-809.

Haidar HA. Emirates pre-service and in-service teachers' views about the nature of science. Int J Sci Educ. 1999;21(8):807-22.

Hallgrimsson B. The false dichotomy evolution versus intelligent design. Evol Biol. 2008;35:1-3.
Hatch JA. Doing qualitative research in education settings. New York: State University of New York Press; 2002.

Hermann RS. Evolution as a controversial issue: a review of instructional approaches. Sci Educ. 2008;17:1011-32.

Hofer B. Dimensionality and disciplinary differences in personal epistemology. Contemp Educ Psychol. 2000;25:378-405.

Hokayem H, BouJaoude S. College students' perceptions of the theory of evolution. J Res Sci Teach. 2008;45(4):395-419.

Ingram EL, Nelson CE. Relationship between achievement and students' acceptance of evolution or creation in an upper-level evolution course. J Res Sci Teach. 2005;43(1):7-24.

Jenkins EW. Constructivism in school science education: Powerful model or the most dangerous intellectual tendency? In: Bevilacqua F, Giannetto E, Matthews MR, editors. Science education and culture: The contribution of history and philosophy of science. London: Kluwer Academic Publishers; 2001. p. 153-64.

Leonard WH. The US biology education standards, new biology curricula and results. Journal of Biology Education. 2004;38 (3): $108-12$.

Lombrozo T, Shtulman A, Weisberg M. The intelligent design controversy: lessons from psychology and education. Trends Cogn Sci. 2006;10(2):56-7.

Lombrozo T, Thanukos A, Weisberg M. The importance of understanding the nature of science for accepting evolution. Evolution Education Outreach. 2008;1(1):290-8.

Matthews MR. In defense of modest goals when teaching about the nature of science. J Res Sci Teach. 1998;35(2):161-74.

McCarthy S, Sanders M. Broad classification and the provisional nature of science. Journal of Biology Education. 2007;41 (3): $123-30$.

Miller JD, Scott EC, Okamoto S. Public acceptance of evolution. Science. 2006;313:765-6.

Moore R. The revival of creationism in the United States. Journal of Biological Education. 2000;35(1):17-21.

Moore R. The differing perceptions of teachers and students regarding teachers'emphasis on evolution in high school biology classrooms. Am Biol Teach. 2007;69(5):268-71.

Moore R, Mitchell G, Bally R, Inglis M, Day J, Jacobs D. Undergraduates' understanding of evolution: ascriptions of agency as a problem for student learning. Journal of Biology Education. 2002;36(2):65-71.

National Research Council. The national science education standards. Washington, DC: National Academy Press; 1996.

National Research Council. Teaching about evolution and the nature of science. Washington, DC: National Academy Press; 1998.

O'Brien T. A toilet paper timeline of evolution: $5 \mathrm{E}$ cycle on the concept of scale. Am Biol Teach. 2000;62(8):578-82.

Peker D, Comert GG, Kence A. Three decades of anti-evolution campaign and its results: Turkish undergraduates' acceptance and understanding of the biological evolution theory. Sci Educ. 2010;19(6-8):739-55.

Rees PA. The evolution of textbook misconceptions about Darwin. Journal of Biological Education. 2007;41(2):53-5.

Sayın U, Kence A. Islamic scientific creationism: a new challenge in Turkey. Reports of the National Center for Science Education. 1999;19:18-29.

Scharmann LC. Teaching evolution: designing sucsessful instruction. Am Biol Teach. 1993;55(8):481-6.

Scharmann LC. A proactive strategy for teaching evolution. Am Biol Teach. 2005;67(1):12-6.

Sinatra GM, Southerland SA, McConaughy F, Demastes JW. Intentions and beliefs in students' understanding and acceptance of biological evolution. J Res Sci Teach. 2003;40 (5):510-28. 
Strauss A, Corbin J. Basics of qualitative research. London: Sage; 1998. Taşkin O, Çobanoğlu EO, Apaydın Z, Çobanoğlu H, Yılmaz B, Șahin B. Lisans öğrencilerin kuram kavramını algılayıșları [Perceptions of undergraduate students regarding the term theory]. Boğaziçi University. Journal of Education. 2008;25(2):35-51.

Terry M. One nation, under the designer. Phi Delta Kappan. 2004;86 (4):265-70.
UKD v. MNE, 7th Administrative Court Ankara, Court case number: 2006-1745. (2006).

Zaman Newspaper. (2009). TÜBİTAK yönetecileri içiniz rahat olsun [The administration of TÜBİTAK feel comfortable]. Retrieved December 29, 2009, from http://www.zaman.com.tr/haber.do? haberno $=824764 \&$ title=yorum-irfan-yilmaz-tubitak-yoneticileriiciniz-rahat-olsun. 